\title{
The Croatian path from socialism to European membership through the lens of technology transfer policies
}

\author{
Jadranka Švarc ${ }^{1}$ (D) $\cdot$ Marina Dabić ${ }^{2,3}$ (D) \\ Published online: 15 April 2019 \\ (c) The Author(s) 2019
}

\begin{abstract}
The transition from a socialist economy to one of capitalism brought, to many countries that had previously been socialist, a drastic decline in their technological competences, technological transfers, and research activities after the 1990s. This research seeks to assess whether or not the policy of technology transfer practised during the socialist era improved for these countries following their entry to a capitalist regime and their subsequent joining of the European Union, and whether or not these two processes (which historically coincide for many previously socialist countries) correlate. Croatia is used as an example of a typical transition country possessive of a specific type of market socialism, with controversial outcomes arising from its particular transition process in comparison to its peers. Despite the assistance of the European Union, which helped many new members from socialist backgrounds to recover their economies by upgrading their technological capabilities, this research reveals that technology transfer in less technologically developed countries is unfolding very slowly. Technological transfer occurs as a highly contextual phenomenon, dependant not only on the structure of the economy and technological and research capacities, but also on the political economy and the type of capitalism. This research identifies the three phases of the evolution of university technology transfer: science based models in socialism; endeavours towards an innovation based model throughout the transition period; and the bureaucratic model, driven by the EU cohesion policy and facilitated through access to the European Structural Funds. This research points out that bureaucratic-driven types of technology transfer should be coupled with nationally concerned actions on overall economic and political reforms in order to gain efficient results from their technology transfer efforts.
\end{abstract}

Keywords Technology transfer $\cdot$ Policy $\cdot$ Entrepreneurship $\cdot$ Croatia

Marina Dabić

mdabic@net.efzg.hr; marina.dabic@ntu.ac.uk

Jadranka Švarc

jadranka.svarc@pilar.hr

1 Institute Ivo Pilar, Marulicev trg 19, 10000 Zagreb, Croatia

2 Faculty of Economics and Business, University of Zagreb, J. F. Kennedy Square 6, 10000 Zagreb, Croatia

3 Management Division, Nottingham Business School, Nottingham Trent University, Burton Street, Nottingham NG1 4BU, UK 
JEL Classification L $26 \cdot \mathrm{O} 31 \cdot \mathrm{O} 32$

\section{Introduction}

With the international economic integration and global saturation of commodities of all kinds, the generation and exploitation of both technological and service innovations are widely recognised today as the key driving force for long-term socio-economic development. The future development of all contemporary economies, including those in postsocialist countries, is highly dependent on their capacity to generate and exploit various types of innovation and their ability to transfer knowledge and new technologies from the scientific sphere to production, and vice versa. Technology transfer has many different meanings and there is an abundance of multidisciplinary literature on this topic (Wahab et al. 2012; Bozeman et al. 2015). Scholars' understanding of what is important in the management of knowledge and technology transfer has evolved continuously, but scientific research, innovation and, recently, entrepreneurship are considered to be inseparably intertwined with technology transfer (Audretsch et al. 2012). While some think that technology transfer is all about technological and managerial learning in companies, growing numbers of scholars since the 1990s have become increasingly more preoccupied with university technology transfer (UTT) (Allen and O'Shea 2014; López Mendoza and Mauricio Sanchez 2018; Breznitz and Etzkowitz 2016), which usually involves the commercialization of research results, different models of science/industry cooperation, and academic entrepreneurship. This approach has resulted in a large expansion of literature in this area, and this was mainly inspired by the ideas of the third university mission, initiated by the third university revolution (Etzkowitz and Viale 2010), the model of the triple helix (Etzkowitz 2008), academic capitalism (Slaughter and Leslie 2001; Rhoades and Slaughter 1997), and entrepreneurial university (Gibb and Hannon 2006; Silva et al. 2018). These theories and ideas have found fruitful grounds for policy applications in European development strategies; firstly within the Lisbon agenda (European Commission 2000) and most recently within the smart specialization strategy (S3) (Foray et al. 2009; Radošević et al. 2018), which established the concept of entrepreneurial university and figured university technology transfer as a fundamental mechanism to spur regional economic growth.

Following this, technology transfer in this study addresses the processes of knowledge transfer from the scientific to the business sector, and all types of academic engagement involving the cooperation of the science with industry (Perkmann et al. 2013; Breznitz and Feldman 2010). It goes beyond the pure commercialization of research results and involves both formal and informal channels of knowledge transfer between academics and stakeholders within an innovation system. Miller et al. (2018) identified, for example, thirteen types of modes of engagement to encourage academics to participate in knowledge transfer ranging from the level of formality, to networking, to spin-outs; while (Dabić et al. 2016) identified the eight basic functions of an entrepreneurial university, of which technology transfer was one of the most prominent.

The key research questions addressed in this article are whether or not the transition to capitalism and membership in the EU changed the university technology transfer model practised in the socialist era and, if so, in what direction; whether the academic knowledge and research was infused into valuable economic activity and marketable innovation that would foster entrepreneurial innovation, or not; and whether knowledge transfer and the 
propensity to engage in entrepreneurship following capitalism were enhanced and, if not, why?

This research was conducted using Croatia as its subject: the newest, 28th EU member state as of 2013, and a country with controversial outcomes of the transition process in comparison to its peers. This controversy stems from the fact that Croatia was much more prepared for market economy in 1990s, and had numerous advantages over countries from socialistic blocks, in terms of price liberalisation, foreign trade liberalisation, and reformation of the banking system (Uvalić 2018), leaving other Eastern European countries, at that time, behind. Nowadays, by contrast, Croatia is one of the least developed EU member states, lagging behind its eastern peers in growth rates of GDP and competitiveness of economy. It remains an upper middle-income country, with a GDP per capita of 11.806 EUR in $2017,{ }^{1}$ which achieved around $60 \%$ of the EU-28 average, however future economic prospects are ambiguous.

This research is conceptual, using the case study of Croatia to better understand how technology transfer and entrepreneurial innovation are determined by the political economy in a national context. The arguments in this article are three-fold. Firstly, we argue that UTT has not essentially changed today in comparison to socialism, as the socio-economic context remains adverse to innovation and entrepreneurialism, despite its transformation to capitalism. Secondly, we argue that UTT has evolved through three models since socialism: the science-based model practiced in socialism; the innovation based model in transition; and the bureaucratic model of today. Thirdly, we argue that the current bureaucratic UTT model is driven by the Europeanization of national research and innovation policies, embodied in the smart specialization strategy, and in certain aspects of regression with regards to the two previous phases of UTT.

The article is structured as follows: in the next four sections the historical evolution and the main features of UTT are described, following on from socialism (Sect. 2), over the first (Sect. 3) and second (Sect. 4) phase of transition, to the present state of Europeanization of UTT (Sect. 5). Discussion of the results of the research is given in Sect. 6, leading on to some concluding remarks in Sect. 7.

\section{Theoretical framework}

Schumpeter (1942) and Drucker (1985) posited entrepreneurial innovation as the source of productivity growth. This approach cultivated a view in which innovation and entrepreneurship were virtual synonyms which could be used interchangeably (Acs and Audretsch 2005), which had a negative collateral effect on the entrepreneurship. The term 'entrepreneurship' almost disappeared from the European scholarly agenda from the early twentieth century to the $1980 \mathrm{~s}$. The focus, in this period, was orientated towards science-based innovation and high technology sectors, carried out by large corporations and research institutes. The analytical framework used to study innovation was the national system of innovation (Nelson 1993); a concept conceived within the evolutionary economy (Nelson and Winter 1982) which focused on the institutions and structures that would foster researchbased innovation (Edquist and Lundvall 1993) in which an entrepreneur was absent or personified in big industries and large corporations (Autio et al. 2014; Acs et al. 2014).

${ }^{1}$ http://www.hnb.hr/en/statistics/main-macroeconomic-indicators. 
This concept of entrepreneurship was productive in the post-war economic regimes of the managed economy, but significantly changed with the massive downsizing and restructuring of many large firms, which gave rise to entrepreneurial economy (Thurik et al. 2013) and brought individual entrepreneurs to the centre of the innovation system (Acs et al. 2017). Scholars gathered around the GEDI project (Global Entrepreneurship and Development Index) (Szerb et al. 2013a, b), which established the theoretical foundation of entrepreneurship capital (Audretsch 2007); entrepreneurship society and economy (Thurik et al. 2013); and the national system of entrepreneurship (European Commission 1995; Szerb et al. 2013a, b; Acs et al. 2014), which essentially replaced the national innovation system. These concepts, along with the construction of entrepreneurship as a separate research field (Carlsson et al. 2013; Landström and Harirchi 2018), marked the rise of a new era of entrepreneurial economy in which entrepreneurship re-emerged as a key agenda of economic policy.

However, a gap between entrepreneurship based on the narrow types of science-based innovation, which take place at technological frontiers (Autio et al. 2014, p. 1099), and traditional entrepreneurship simply based on new ventures neglecting technological innovation, still persists. The first type of entrepreneurship was inherent to a managed economy, while the latter is implicit in entrepreneurial economy. Traditional entrepreneurialism, which is often likened to just "another shop around the corner" (Block et al. 2013, p. 713), lacks the innovation dimension and has previously been seen to threaten technological progress and economic growth in the long run (Shane 2009). Discussions concerning the exploitation of new knowledge within the knowledge spill-over theory of entrepreneurship (KBST) (Audretsch and Caiazza 2016) and knowledge-driven entrepreneurial economy (Audretsch and Link 2018) definitely have a place within this context.

On the other hand, it seems that a concept of entrepreneurial innovation that has recently entered the academic fora (González-Cruz and Devece 2018) could bridge the aforementioned gap, as entrepreneurial innovation assumes opportunity driven businesses (Mrozewski and Kratzer 2017) with a high potential for growth (Guerrero, and Urbano 2017). Entrepreneurial innovation is focused, as well as summarized by Autio et al. (2014, p. $1105)$, on radical innovation, and can generate growth without necessarily involving scientific research and infrastructures, which is a rather illusive feat for many entrepreneurs. Its nature and performance is determined by the different contexts of entrepreneurial innovation ecosystems (industrial, organizational, temporal, etc.), which generate different types of entrepreneurial innovation.

However, it seems that the concept of entrepreneurial innovation is still theoretically and analytically vague and remains insufficiently distinctive from other forms of entrepreneurship. This entrepreneurship innovation is discussed from many angles such as: the narrative perspective of contextualizing innovation through relational, temporal, and performative efforts (Garud et al. 2014); its role for emerging economics within the model of the triple helix (Guerrero and Urbano 2017); interaction between opportunity and necessity entrepreneurship (Mrozewski and Kratzer 2017); its role in regional competitiveness and entrepreneurial university (Guerrero et al. 2016); the intelligence of the intellectual class (Burhan et al. 2017); and governance quality and economic freedom in the EU (Ignatov 2017), to name but a few of the theoretical approaches.

Following the ideas of Guerrero and Urbano (2017) and (Guerrero et al. 2016), entrepreneurial innovation can be understood to be a new technology entrepreneurship initiative which involves different kinds of university technology transfer (cooperative search, business incubation, etc.) and cooperative knowledge generation, through models such as that of the triple helix (Etzkowitz 2008). 
When it comes to transition economies, it could be argued that the entrepreneurial innovation or commercial exploitation of knowledge hardly exists (Kornai 2010; Švarc 2014; Krammer 2009). Croatia suffers from the same shortcomings in terms of innovation and entrepreneurship regardless of its transition to capitalism and irrespective of its embracing of the principle of entrepreneurial economy (Thurik et al. 2013).

These reasons can be found in the inheritance of socialism and, on the other hand, in the particular processes of entrepreneurship development in the transition period. During socialism, private ownership was largely discouraged because it signified alienation from "social ownership" and compromised the principals of self-managing socialism (see the next section). When the planned economy collapsed, the population inherited slacked entrepreneurship capital (Audretsch 2007, 2018) and lacked entrepreneurial experience, skills, and institutions (Estrin and Mickiewicz 2011), which made the transition a nightmare (Ignatov 2017).

While the practice of university technological transfer largely relied on the legacy, practice, and scientific technological resources of ex-Yugoslavia, the development of entrepreneurship was rather uncharted territory. With no historical foundation, entrepreneurship has been developing according to two different plans. The first plan involved a new type of "political entrepreneurship" (Kshetri 2009) driven by tycoons' non-transparent privatization of state enterprises, which led to today's crony capitalism (Franicevic and Bicanic 2007). Crony capitalism has had a disastrous impact on innovation dynamism and proinnovation culture as it is considered to be a speculative (often criminal) form of entrepreneurship which displaces productive and innovation-based businesses. Innovation has lost its plausibility, social value and, economical effectiveness ( $\breve{v a r c} 2017$ ).

The second plan was developed quite separately from the privatization process and included the development of new small and medium-sized enterprises (SMEs). This new sector was encouraged by public policies, strategies, laws, and regulations, and through the state supporting programmes where integration with the European Union played a key role. The process started with the adoption of the European Charter for Small Enterprises in 2003, which recommended ten key policy areas of action to support SMEs. The implementation of this was subjected to regular monitoring and evaluations (Švarc 2014). Owing to the Europeanization of entrepreneurship policy, Croatia put in place the basic legal and regulatory frameworks for SMEs rather quickly. The government started the nationwide "Business impulse" programme to develop business capacities and support primarily traditional types of businesses. However, the technological and innovation capacities of the firms were rather neglected (mainly limited in terms of their acquisition of the new equipment) and involved quite limited relationships with universities as a source of business competitiveness. Therefore, neither crony or "political" entrepreneurship nor the new SMEs sector nurtured entrepreneurial innovation. University technology transfer has developed along its own path, which is presented in the next sections with reference to entrepreneurship innovation where appropriate.

\section{UTT in socialism and the position of Croatia in ex-Yugoslavia}

There is a vast amount of literature concerning the rise and fall of eastern socialistic economies, including Croatia and ex-Yugoslavia (Bartllet 2003; Dyker 2011; Dyker and Vejvoda 2014), as well as numerous case studies on particular countries' transitions of 
research and innovation systems following socialism, which are well summarized in Meske (Meske 2000a, b) and Dyker and Radošević (1999).

It is commonly perceived that industries in Croatia within ex-Yugoslavia have grown very quickly following the Second World War, when large industrial corporations were extended or founded, such as Podravka (food), Pliva (pharmacy), Rade Končar (electrical equipment), RIZ (electronics), Nikola Tesla (telecommunications), and Đuro Đaković (machinery), to mention only a few. In some technological sectors, ex-Yugoslavia has kept pace with developed western countries, and even exported technical services to Arab countries (Radošević 1994). Croatia was one of the six republics of Yugoslavia and, with the exception of Slovenia, was the most developed republic, boasting a relatively strong industrial base. According to some estimations (Stipetić 2012), Croatia had its greatest GDP growth between 1950 and 1973 and, at the end of this period, even surpassed countries within Central Europe, such as Hungary and Poland, and was only eclipsed by Czechoslovakia and Slovenia.

Most large corporations had in-house research institutes, which cooperated with different faculties and with the largest Croatian institute for natural sciences-Institute Ruđer Bošković-which was established in the 1950s for nuclear research. However, the knowledge-orientated basis for the development of proprietary technologies was insufficient, and thus the import of foreign technologies was the basis of technological development. The type of imported technology depended on the technological maturity of the sector and varied from low technological loan jobs in the textile industry, to various licence contracts, consultations, and know-how, to the acquisition of complete "turn-key" services.

Nevertheless, it is important to stress the specific role that science plays in ideology and in the politics of socialistic economies, including those within Croatia. It is considered to be an important condition for economic development and is the main element of historical competition with the West (Meske 2000a). Science thus receives a lot of support from the government, including in-house industrial institutes, which sometimes result in the over-extension of research staff. When it comes to science-industry cooperation and knowledge transfer, it is commonly agreed that the East and West have developed according to radically different logics (Hanson and Pavitt 1987; Högselius 2003). The main difference between the East and West is that innovation in the East was not spontaneously driven by the interest of stakeholders, but was centrally coordinated by the state, limiting the mutual co-evolution of industry and science in creating technical change. This substantial difference is a logical consequence of the political economy of socialism and capitalism, as a socialistic economy is based on the central planning of economy and state paternalism (the paternalistic relationship between the state and the firm) rather than market competition and private initiatives. This considerably reduced the willingness of companies and research institutes to respond to market incentives through innovation and marketable research. The central planning of innovation resulted in the fragmentation of the innovation system, which prevented the integration of $R \& D$ and production and inter-organisational learning.

Another essential fault of technological policy in socialism was the supposedly linear model of innovation (in which innovation takes place in consecutive phases from research to invention and innovation) or the science-push approach, which established science as the primary instigator of innovation and technological change. It is often forgotten that the science-based model of innovation was not only a dominant theoretical model in the West, in the period from the Second World War to the 1970s, but was also practiced by companies (Balconi et al. 2010, p. 3). 
The remaining shortcomings include the absence of small firms or "specialised suppliers", very few technological trajectories, and a lack of appropriate selection environments (Hanson and Pavitt 1987); as well as imbalances between production capacities and absorptive capacities, technological obsolescence of equipment, imbalances in the production chain, and others (Radošević 1994).

Although Croatia shared the majority of these shortcomings with other countries of the Soviet bloc, its system of innovation had certain advantages compared to the Soviet system. Croatia, as a part of ex-Yugoslavia, developed a network of relatively strong missionoriented public and industrial research institutes, this was a stark contrast to the Soviet model, in which the Academy of Sciences was a superior scientific institution and the main producer of basic research. Besides. Yugoslavia developed specific workers' self-managing socialism and, within it, a specific institutional set-up for science-industry cooperation"the self-managing interest communities for science"-whose purpose was to lead science policy from a republic level, and mediate the "labour exchange" between suppliers (research organizations) and recipients of science (industry). In this way, research organizations in Croatia were funded from the state and from the production sector in two ways: via the "direct exchange of work" (direct contract with industry), or via "indirect exchange of work" mediated by the self-managed interest communities for science. Regardless of the efficiency of this funding, this shows that the government of ex-Yugoslavia has been aware, since the 1970s, of the importance of supporting the "links between knowledge and economic development" (IDIS 1980, p. 12), and has sought to encourage the "exchange of work" between research and industry. According to some estimations (Pisk 2001), "Institute Rudjer Boskovic" in 1989 accounted for $40 \%$ of its funds from the production sector, including the army, but these funds were reduced in 1999 to only 13\%. As we shall illustrate, such levels of science/industry cooperation would not be achieved in later periods, even up to the present.

\section{Methodology}

A longitudinal case study approach is used in this research to analyse the evolution of university technology transfer and its relation to entrepreneurial innovation over the last 30 years, during the transition from socialism to capitalism. It offers a discussion of the evolution of the UTT and entrepreneurial innovation from socialism to the current Europeanization of the technology transfer policies, through the historical overview of the three phases of UTT evolution, exemplified by Croatia.

The research includes the analysis of a number of strategic documents, laws, programmes, regulations, and reports on scientific and innovation policies in Croatia, from the mid-1990s to the most recent S3 strategy, supported by statistical data (e.g. Eurostat) and other relevant data from international resources (e.g. GEM, Doing Business Indictors) to capture main actors, funding trends, and policies regarding technology transfer and innovation challenges. This approach provides a theoretical insight and a critical reflection concerning the meaning of technology transfer and entrepreneurial innovation in different socio-economic contexts over time. Important resources include the country reports of OECD, World Bank, and the European Union (such as Erawatch/RIO reports) since their 
commencement in 2006, ${ }^{2}$ as well as the recent HEInnovate background report carried out in 2018 by Dabić for the OECD/EC.

\section{Findings}

\subsection{First phase of transition: policy learning and establishing initial infrastructures}

Croatia became an independent state of ex-Yugoslavia in 1991, at which point it begun its journey towards a modern capitalist economy. During the first turbulent decade of its independence, Croatia laid the foundations for new state institutions, exchanged its single-party system for parliamentary democracy, created its own new currency, repaired large-scale homeland war damages, and initiated reforms for its transition to a market economy.

The Croatian R\&D sector has undergone, like all post-socialist countries, a similar process of restructuring, ranging from "shock without therapy" (Radosevic 1996) to a gradual restructuring of research infrastructures and the organization of science activities. The science base in Croatia, in terms of both human/resource capacities and investment in R\&D, has shrank significantly (Prpić 2003) but the old socialist elitist approach to science, along with the linear model of innovation, helped to preserve the national knowledge base of public R\&D during this turbulent transition period while the national economy was brought to ruin. In contrast, industrial $\mathrm{R} \& \mathrm{D}$ has undergone serious deterioration, corresponding with low-levels of absorption capacity in firms in terms of research and technology transfer. In line with the tremendous loss of industrial production during the 1990s, mainly due to the breakdown of export markets during the process of the privatization of state owned companies, many leading technological companies (with 50 years of accumulated knowledge and technological competences) collapsed or were absorbed by foreign companies. These losses in industrial production in sectors with higher levels of technology content can be considered as one of the most severe transformations, with devastating consequences on technological development and transfer. Supply and demand for R\&D and technological development either vanished or was greatly reduced. This process is perceived by sociologists as the "empty-shell model" of privatization (Županov 2001), which denotes the extraction of the company's substance by tycoons and corrupt managers, usually culminating in the devastation of a company's fixed assets and technological competences.

Similar devastation processes were also present in other post-socialist countries (Poland, Hungary, Slovenia, etc.) but these were mitigated by the countries' membership in the EU and through their integration into the European techno-economic networks. Unlike these countries, Croatia was disabled by this process due to homeland war and the subsequent isolation of the European integration process until 2013. R\&D and innovation were not the focus of the governmental agenda, as it was expected that innovation and technology development would be generated spontaneously as the result of companies' privatization, macroeconomic stabilization, and trade liberalization (the holy trinity of transition). The fact that technology transfer was not an automatic and spontaneous process, which would follow from foreign direct investments and market liberalization, was overlooked. Instead, endogenous research and technological capacities, together with private initiative and entrepreneurial activities (which were suppressed during socialism) were needed.

\footnotetext{
${ }^{2}$ Available at: https://rio.jrc.ec.europa.eu/en/country-analysis/Croatia/country-report.
} 
From a global perspective, the shift in modes of technology transfer in the late 1980s from cross-national technology transfer, especially from industrialized nations to less developed nations, towards domestic technology transfer, can be linked to the need for a more pro-active role of the state in supporting new technologies and national competitiveness (Bozeman et al. 2015). Policies concerning the theory and practice of innovation and knowledge-based growth became a significant objective for policy-makers in the early 1990s (Mytelka and Smith 2002), and Croatia was no exception to this, particularly with regard to the evolutionary theory of technological change (Nelson and Winter 1982) and the concept of the national system of innovation (Freeman 1988). Both of these concepts perceive innovation as a phenomenon endogenous to society and economy, a social construct (OECD 1992) which requires an appropriate institutional support and deliberate policy actions to facilitate the smooth flow of knowledge between different sectors, primarily industries and universities. The most attractive of these was the concept for an innovation system in which the competitiveness of a nation does not depend on the scale of R\&D, but rather "[...] upon the way in which the available resources are managed and organised" (OECD 1992:80). It provides a hope that even a small country with limited resources, like Croatia, could make rapid progress and technologically leapfrog. South Korea, Ireland, and Finland serve as examples of this.

The learning of policies and the beginning of the Croatian innovation system can be traced back to the mid-1990s, when the Ministry of Science and Technology (today Ministry of Science and Education) made efforts to transfer advanced "Western" models of science/industry cooperation and financial support to innovative small and medium-sized enterprises. Technical assistance projects with Germany and Italy provided necessary expert knowledge for the modernization of Croatia's technological policies and technology transfer (Lange and Švarc 1994). ${ }^{3}$ This first phase of launching the Croatian innovation system, which lasted until 2000, was focused mainly on technological infrastructures and resulted in the establishment of the first technology innovation centres in three university cities, Zagreb, Split, and Rijeka, closely followed by Osijek and Dubrovnik. These centres are still in function but now operate on more commercial principles.

Importantly, cooperation with Italy resulted in the establishment of the Business Innovation Centre of Croatia (BICRO), the pillar institution of the whole innovation system, with a mission to create financial models and instruments to support innovative or researchbased entrepreneurship and allow for possible evolution into the national development agency (like, for example, the IDA in Ireland). This has, unfortunately, never happened. BICRO passed many organizational and structural transformations, however it ceased to be in 2014 when it was merged with the Croatian Agency for Small Business, Innovation, and Investment (HAMAG). This large agency had little over a hundred employees, whose main task was to implement programmes funded by the ESIF within the cohesion policy of the EU.

HAMAG-BICRO also provided support to Technology Transfer Offices in Croatia (TTO Programme). The programme was focused on strengthening the role of TTOs in universities and public research institutions, as these represent central locations for encouraging and conducting technology transfer activities. The programme was funded from the budget for STP II, which was funded by the WB loan. Currently there are five TTOs in Croatia, all

\footnotetext{
3 The projects were made within bilateral cooperation of the Ministry and the German Federal Ministry of Research, Science, Education and Technology using the expertise of FhG-ISI, Karlsruhe and VDI/VDE-IT, Berlin and with the Business Innovation Centre Friuli -Venezia Giulia, Trieste.
} 
with the main objective of providing support to researchers in public science organisations in every phase of technology implementation, including the identification of ideas, market potential, the processes of protection and commercialisation of IP, and the establishment of spin-off/spin-out companies.

\subsection{Second phase: the "golden age" of the innovation-driven mode of UTT}

The second phase of establishing the Croatian innovation system was marked by the launch of a programme called HITRA in 2001 (MoST 2002). This was the first nationwide government programme in innovation policy-making. It was a reflection of the desire of the new left-oriented government, who won power in the 2000 elections, to give momentum to innovation and technology development. HITRA was "a sort of diversion among the elitisttype oriented scientist while, for entrepreneurs, it was just a new trendy initiative of public administration with no significance for the real business" (Švarc 2011, p. 145). HITRA treats the national innovation system as a complex dynamic structure, wherein a system's efficiency can be anticipated by its three constitutive parts: policy measures and programs; technological institutional infrastructure; and control mechanisms for monitoring system performance. The first HITRA programmes included the development of commercially promising products and services from research organizations, prior to their commercial stage, and a programme for the development of knowledge-based companies, aimed at both entrepreneurs and scientists. These programmes were subsequently upgraded and extended by a number of other innovation supporting programmes, of which the Proof of Concept (PoC), introduced in 2010 with the aim of ensuring pre-commercial capital for the technical and commercial testing of innovation concepts, was the most successful.

Public administration designed HITRA rather ambitiously, tasking it with motivating scientific research to foster science-industry cooperation, reviving industrial R\&D, and encouraging the commercialisation of research results in order to support competition within the economy (Švarc 2011). This phase of UTT development can therefore be treated as innovation-driven technological policy-at least, when "good intentions" are considered.

However, the reality of HITRA's programmes in practice presented many obstacles which prevented this innovation-based model of UTT from achieving its full potential. First of all, HITRA was faced rather early on with a lack of "systemic" innovation policy (Kuhlmann 2001). Many projects are obstructed by the deficiencies of the remaining parts of the innovation system, which are beyond the sphere of research and beyond the scope of HITRA itself; for example the lack of a sound policy concerning intellectual property protection, lack of venture and risk capital, absorption capacities of companies, etc. The Croatian government has not undertaken sufficient efforts to promote innovation policy at a national level, nor coordinated and harmonised the different ministries' efforts towards technological development. Nonetheless, the "division of work" and competences between the line ministry of science and the economy have persisted. The fact that technology transfer processes imply that functional, organizational, disciplinary, or national and cultural boundaries need to be spanned was overlooked.

On the other hand, the mind-set of leading politicians and intellectuals did not change much in terms of understanding innovation as an interactive process, embedded primarily in firms. However, the linear process, which has been the dominant approach since the 1970s, persisted as they failed to understand that technology transfer is based on a multichannel interactive model which does not necessarily involve R\&D, and that innovation 
is primarily linked to firm-based learning and knowledge acquisition in the production process (engineering, testing, marketing, organisation), while explicit R\&D and links to research institutions is only a small part of these activities, if any (OECD 1998).

Innovation systems and policies have thus developed within the wide framework of science policy, and yet have only occupied a peripheral position due to the strong resistance of the scientific community towards the "commodification of science", and their efforts to preserve the traditional role of science as an "ivory tower". The majority of scientists have resisted change, particularly with regards to scientific commercialization rather than to scientific ethos and principles. Studies of science-industry cooperation in Croatia have revealed rather weak connections between these sectors (Vehovec and Radas 2006; Radas 2006; Jeleč Raguž and Mujić Mehičić 2017) as well as weak entrepreneurialism in Croatian universities (Dabić et al. 2016).

The elitist approach to science and the focus of industrial policies on privatization and FDI, which ignored engineering, applied sciences, and technologies, has hampered the recognition of innovation and technological transfer as the driving force of economic growth. For these reasons, HITRA remained fragmented initially, unable to spur knowledge-based growth as its main task. By 2013, when the government initiated major reforms of the research and science development (R\&SD) system, all HITRA programmes were terminated. Despite its termination, HITRA had an irreversible influence on the management of research projects, and brought socio-cultural changes with it, enabling a shift from conventional science policies towards policies that promoted entrepreneurial spirit and knowledge transfer activities in the academic community.

This second phase of innovation policy, which lasted from 2001 to 2010, despite deficiencies, marks the "golden age" of the innovation system. During this decade, the national innovation system (NIS) had become a relatively complex system of supporting programmes, infrastructures, and policy documents for improving innovation dynamics and technology transfer (Švarc 2011). New institutions, such as the Croatian Institute for Technology which develops technology forecasts and strategies, and the Technological Council of the Ministry of Science and Education which provides grants for applied research and technological projects, were established by the mid-2000s. New funds to support knowledge and technology transfer were founded in the period between 2005 and 2009, such as the Unity Through Knowledge Fund (UKF), the Science and Innovation Investment Fund, and the Partnership programme for the science/industry cooperation of the Croatian Science Foundation. The landscape of interface institutions for technology transfer and innovation development was significantly extended in the coming years, with new centres for technology transfer emerging at universities, as well as technology and innovation centres and parks supported by local communities.

Thanks to the EU Instrument for Pre-Accession Assistance (IPA), activated in Croatia in 2007, the large infrastructure - the Biosciences technology commercialisation and incubation centre (BIOCentre)—was supported with over $€ 18$ million, and the Centre began operation in September 2015. The first (and, to this day, only) Science and Technology park at a university was established by the University of Rijeka (StepRi) ${ }^{4}$ in 2008 , with the support of the then BICRO's programme for technological infrastructure development (TEHCRO). The Science Park and the engagement of the University of Rijeka with the local economy

${ }^{4}$ http://www.step.uniri.hr/o-nama. 
Table 1 Population by educational attainment level, tertiary education (levels 5-8), and age (\%). Source: Eurostat, online data code (edat_lfse_03)

\begin{tabular}{lllllllllll}
\hline Age/GEO & 2007 & 2008 & 2009 & 2010 & 2011 & 2012 & 2013 & 2014 & 2015 & 2016 \\
\hline From 25 to 64 years & & & & & & & & & & \\
European Union (28 countries) & 23.5 & 24.2 & 25.1 & 25.9 & 26.8 & 27.7 & 28.6 & 29.3 & 30.1 & 30.7 \\
European Union (27 countries) & 23.6 & 24.3 & 25.2 & 26 & 26.8 & 27.8 & 28.7 & 29.3 & 30.1 & 30.8 \\
Croatia & 15.8 & 16.2 & 17.2 & 18.6 & 18 & 18.5 & 19.8 & 21.3 & 22.7 & 23 \\
From 25 to 34 years & & & & & & & & & & \\
European Union (28 countries) & 29.9 & 30.9 & 32.3 & 33.3 & 34.4 & 35.5 & 36.4 & 37.2 & 37.8 & 38.2 \\
European Union (27 countries) & 30 & 31 & 32.3 & 33.4 & 34.5 & 35.6 & 36.5 & 37.2 & 37.9 & 38.3 \\
Croatia & 17.8 & 19.9 & 21.3 & 25.8 & 24.4 & 23.6 & 27.3 & 31.9 & 30.8 & 32.8 \\
\hline
\end{tabular}

made this university almost the ideal entrepreneurial university: striving to implement a triple helix model of the industry-science-government relationship in practice.

Higher education attainment levels at present are generally on the rise in the EU and Croatia, and this trend is clearly to be welcomed, given the fast-evolving knowledge economy challenges that are being faced (Dabic et al. 2015) (Table 1).

Seeking to increase entrepreneurship in the Faculties of Economics and Business in Zagreb, Faclty of Economics and Tourism "Dr. Mijo Mirković" in Pula and Faculty of Economic in Split, Croatia implemented project "Fostering Entrepreneurship in Higher Education" (FoSentHE), which was granted by the European Commission. The FoSentHE project was dedicated to the promotion of entrepreneurship amonsg students and to the generation of interest in scientific commercialization (Dabic et al. 2012).

\subsection{Present state: Europeanization of technology transfer policies and practices}

From 2010 onwards, the innovation system landscape was gradually reshuffled and, by 2013, almost all institutions and programmes launched during the "golden age" were terminated. The Ministry of Economy took over programmes for technology transfer in place of the Ministry of Science and Technology, marking a new era in innovation policy and UTT, which were traditionally under the auspices of the Ministry of Science and Education.

In 2013, the government initiated major reforms of the R\&SD system with regards to funding, organizing, and evaluating scientific work to improve scientific excellence. The reform marked the end of Croatia's innovation system, which had been building since the mid-1990s from a grounding focus on research activities and the supply-side of the innovation process.

As a result of the budget austerity policy, the reform included serious cut-offs of the funds for scientific projects between 2013 and 2016. The reforms coincided with Croatia's entry into the EU in July 2013, which granted access to the European Structural and Investment Funds (ESIF) and allowed for the adoption of Smart Specialization Strategy (S3) as a pre-conditionality for using ESIF. Policy makers believed ESIF would serve to substitute a large portion of the scarce budget resources. Innovation policy and technological transfer in Croatia has become, like in other EU countries, largely determined by the common European strategy of research and innovation (Dabić et al. 2015). ESIF, as a critical source of funds for R\&D in Croatia, which significantly surpasses the national funding abilities for research activities, brought not only money but also its scientific policy (research priorities, 
goals and purpose of research, and financial priorities) as pre-determined by the S3. It led, as Kuhlmann (2001) expected, to the "post-national" innovation systems striving towards centrally mediated policy-making. S3 has not only made dramatic changes, but has significantly affected both innovation policy previously determined by the National Innovation Strategy, 2014-2020, and science policy, which was defined in the Strategy for Education, Science, and Technology, 2014-2020.

Fostering innovation became a strategic goal of the EU in the mid-1990s (Oslo Manuel_ OECD 2005; OECD/European Commission 2004), as Europe experienced growing unemployment, economic stagnation, and fierce competition from the USA, Japan, South Korea, and China. European innovation policy has gradually evolved from the instigation of the "research triangle" of the Lisbon agenda (integration of innovation, science, and higher education policies) towards the Smart Specialization Strategy (Foray et al. 2009) formulated in the Europe 2020 Strategy. S3 was primarily developed as a central element of the new European cohesion policy, which should have enabled all EU countries, especially those less developed, to follow their own path of development. Cohesion policy within the Smart Specialization Strategy is no longer based only on inclusion into the ERA (European Research Area) framework programmes, which is featured by the frustratingly low participation of innovation followers and mainly serves the interest of the most developed countries (Švarc et al. 2013a, b). Innovation followers are also no longer supposed to impartially copy innovation supporting instruments, which usually achieve weak or negligible success in the recipient county.

The Smart Specialisation Strategies Initiative (RIS3) was therefore launched by the European Union as a new approach to economic development, based on the targeted support of R\&D activities and innovation. It set the strategic directions for the development of R\&D activities in the forthcoming period. The Croatian Smart Specialisation Strategy development is coordinated by the Ministry of Economy, Entrepreneurship, and Crafts (MEEC), who drafted the analytical background for the S3 with the support of an EU cofunded expert team. The Smart Specialisation Strategy was adopted by the Croatian government on 30th March 2016.

S3 preserved the basic idea of science/industry/government cooperation but on different premises which allowed different countries to specialise in their own specific sectors, depending on their capabilities. In contrast to previous innovation policies, which followed a centralized top-down approach, the S3 strives to identify research and technology areas for public interventions based on the analysis of the strengths and potential of the local economy through the Entrepreneurial Discovery Process (EDP), which is led by local entrepreneurs. This "strengthening of the strengths" policy focused on entrepreneurs and designed cohesive policies that would encourage regional development and SMEs in technologically peripheral countries in the EU. This has evolved over time into a new industrial and innovation policy for regional development all over the EU (Radošević 2018).

It is commonly perceived that the EU Structural and Investment Funds (ESIF), with a fund of $€ 10.68$ billion for the period 2014-2020, provided Croatia with the remarkable opportunity to address their needs in research, innovation, and skills. It makes $€ 1.5$ billion per year (World Bank 2012), over 3\% of GDP on an annual basis, and about ten times as much as it did from 2007 to 2013 (European Commission 2015). Of these funds, €646.79 million is used with the intention of strengthening the economy by applying research and innovation, as determined by the budget of the Operational Programme "Competitiveness and Cohesion", 2014-2020.

ESIF provides funds for thirteen centres for scientific excellence, the new organization forms of scientific research, and is going to provide resources for the revitalization of many 
research infrastructures, including large ones such as the Institute Ruđer Bošković, Faculty of Electrical Engineering, and university hospitals.

Pre-structural and structural funds have already provided several important grant schemes to support the industrial application of research results and facilitate knowledge transfer from the research sector to the industry sector by strengthening capacities for research, development, and innovation, or increasing the development of new products and services as a result of research and development. In contrast to scarce national resources, the ESIF provides meaningful funds for technology transfer activities. One of the most important grant schemes, for centres of competencies, is expected to contain over $€ 100$ million.

Despite this, there are many new programmes for strengthening the innovation and production capacities of SMEs which do not involve research-based activities. These include "Competence of SMEs" or "Innovation of the newly established SMEs", which has substituted the previous nationally devised programme; and "Business impulse", which was administered and funded by the Croatian government. On the initiative of the government, thirteen competitiveness clusters have been established to provide sector-specific synergies to increase national competitiveness (Anić et al. 2018). Although their role is still rather limited, they are expected to be integrated into the Innovation Network for Industry, and to have an active role in the overall national innovation system.

With regards to the policy framework for entrepreneurial learning, the years of efforts of the Ministry of Economy, Entrepreneurship, and Crafts to establish an entrepreneurial education system are yet to provide tangible results. As a result, educational attainment levels of the population have improved significantly.

The following tables provide an overview of the overall indicators relevant to entrepreneurship and the business sector (Table 2).

Governance for smart specialisation requires strategic capacities and operational jurisdiction to grasp future opportunities, mainly in order to align policy actions, build critical mass, develop a vision, and implement a strategy with respect to the overall EU surroundings (Fig. 1).

For S3, the implementation of action plans for the most relevant investments will be funded under the European Regional Development Fund Operational Programmes (ERDFOP) Competitiveness and Cohesion (OP CC) through two priority axis: Priority Axis 1Strengthening the economy through the application of research and innovation, which will focus on research, technological development, and innovation; and Priority Axis 3-Business Competitiveness, which will provide support for small and medium-sized businesses (SMEs). In parallel, through the ESF-OP Efficient Human Resources (OP EHR), a significant contribution will be provided for S3 implementation in the field of smart skills.

The Entrepreneurial Discovery Process (EDP), as its essential component, used the cooperation of regional stakeholders to identify strategic areas of public investment into the technology and economic competitiveness of SMEs. Universities occupied a critical role as the regional innovation hub and "intellectual" base for local companies' development through technology and knowledge transfer, allowing them to upgrade their technological skills and competences. It seems that the implementation of S3 has finally pointed UTT in the right direction, and it marks two important milestones: firstly, the beginning of a new innovation ecosystem with a stronger focus on companies' needs and regional 


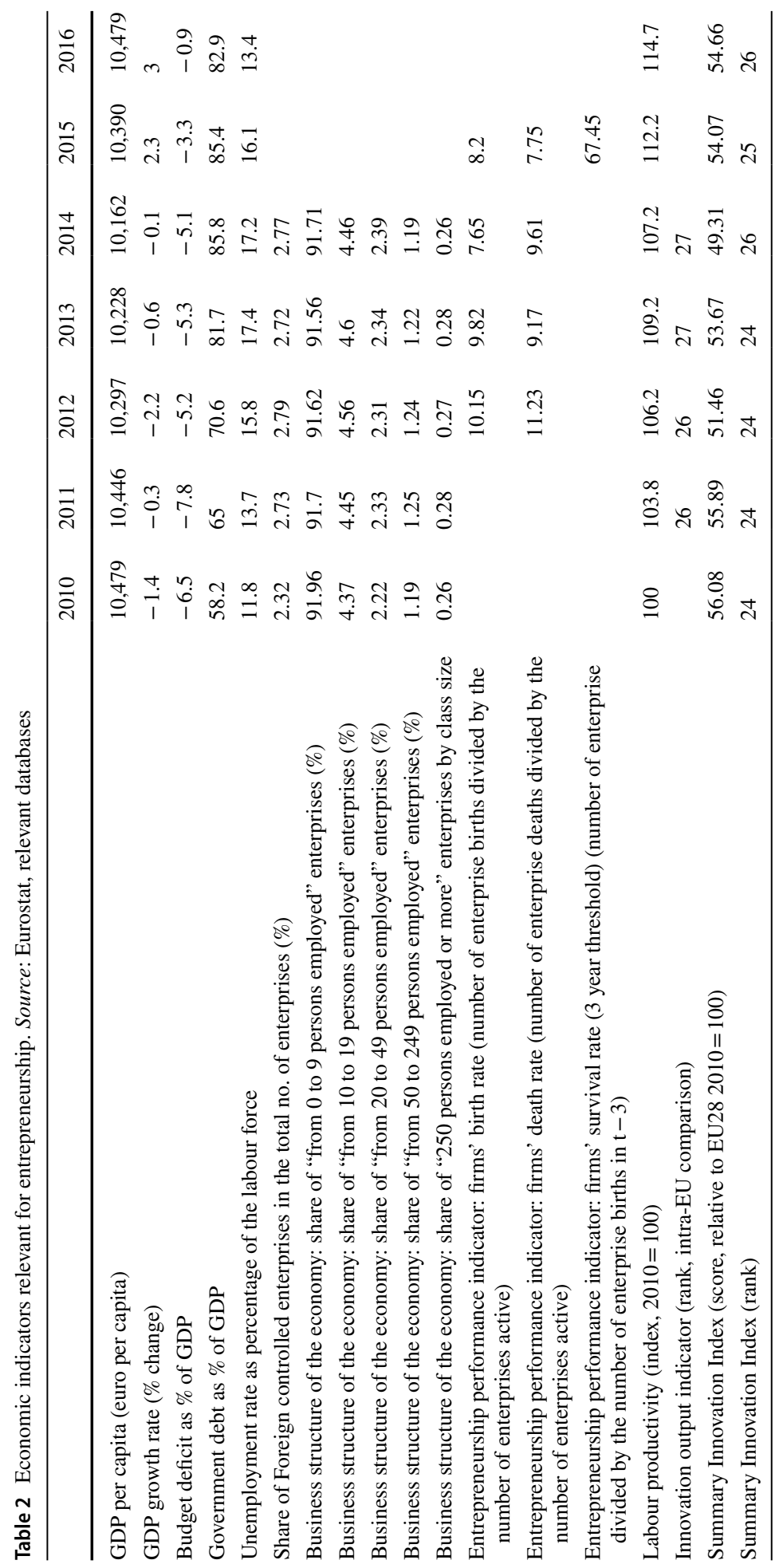




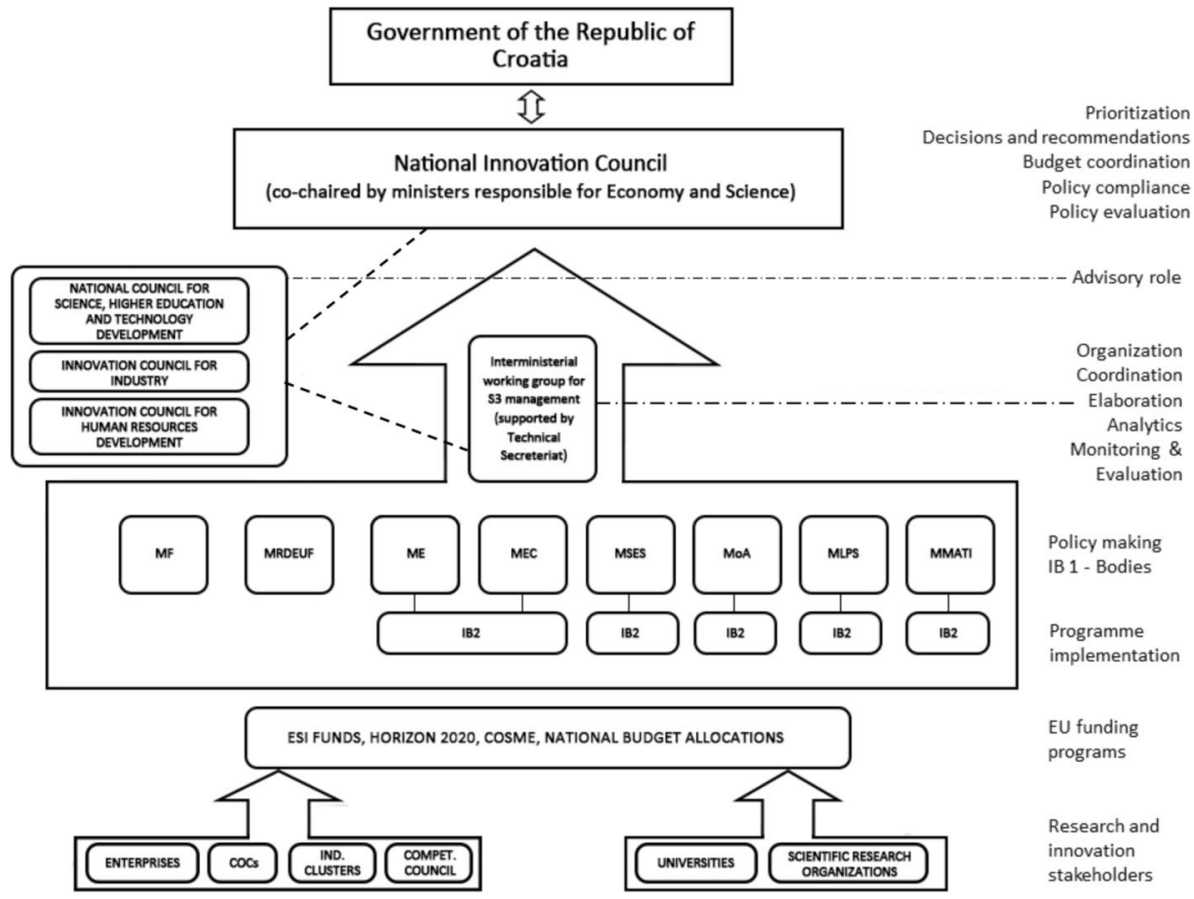

Fig. 1 Governance system for the S3. Source: The smart specialisation strategy of the Republic of Croatia, the Ministry of economy, entrepreneurship and crafts (MEEC)

development, complemented by entrepreneurial culture and spirit; and secondly, the scientific community's efforts to embrace cooperation with companies through knowledge and technology transfer, something that was avoided for almost 30 years.

However, the process of building S3 in Croatia saw the principles of EDP adhered to only in part. The participation of stakeholders, especially those from science and business backgrounds, in the formulation of priorities for the technology transfer from universities to local businesses is rather formal (Mršić 2018). This simply means that organic links between stakeholders in formulating regional technological needs, and the subsequent submission of cooperative projects for ESIF funding based on common interest and importance for the local economy, are harder to find. On the contrary, project activities are mainly driven by the bureaucratic requirements of ESIF operative programmes and the "rules of the game" with regards to project submission, evaluation, and funding. Moreover, initiatives for project submissions regularly come from research organizations as companies are more focused on simply surviving and are less interested in knowledge transfer from universities. It is presupposed that "isomorphic mimicry" (Radošević 2018) will occur, in which EDP only imitates the interaction between the business and research community with the aim to "collect the free money". The fundamental question is not whether such imitations will occur, but in what proportion in relation to projects driven by authentic mutual interests. It seems that, at the moment, technology transfer within ESIF operational programmes is just another top-down "bureaucratic" incentive (this time coming from the EU and not from the national administration) for science-industry cooperation. The only difference this has in comparison to previous government initiatives is access to larger 
amounts of ESIF resources, which can support bigger projects which may have greater potential impact on the economy if cooperation is efficient.

There are also fears that absorption of ESIF will be sub-optimal because of insufficient administrative capacity, burdensome procedures, and a limited number of ready-to-implement projects, as identified in the Recommendation on the National Reform Programme (CEU 2016). Besides, low technological capacities of companies and the structure of the industry could yield little convergence with the EU (Bonaccorsi 2016; Muscio et al. 2015; Archibugi and Filippetti 2011). Such sub-optimal use of ESIF has already been seen in Greece (Liargovas et al. 2016), a country with which Croatia shares many obstacles when using ESIF, such as inefficient administration, corruption, and the declining competitiveness of economy.

Because of the aforementioned limitations, the Strategy for Entrepreneurship Development in the Republic of Croatia, 2013-2020, plans to fulfil the strategic goal of improving overall economic performance by enhancing the economic performance of small businesses in the manufacturing and service sectors. This will be accomplished through more investment into $\mathrm{R} \& \mathrm{D}$, higher degrees of innovation, growth in exportation, and further development of business networks and connectivity.

The main indicators for business performance are presented in Table 3.

Due to poor performance, several policy measures from the Ministry of Economy, Entrepreneurship, and Crafts have been introduced, striving to improve SME competitiveness by ensuring that the relevant standards for export production are met. In light of these measures, SME value started to recover in 2013, ultimately rising by $8 \%$ between 2012 and 2015 .

In 2016, the Ministry of Economy, Entrepreneurship, and Crafts published a call for increasing the development of new products and services arising from R\&D activities"a programme to support business research and innovation (R\&I) as well as cooperation with the public R\&I sector, funded by ERDF, which focuses on developing new products, services, and technologies, and improving business processes by increasing their collaboration with science and research institutions. The total budget for the period between 2014 and 2020 amounted to $€ 205$ million ( $€ 100$ million for the first phase in 2016 , with an additional $€ 105$ million for the second phase in the final quarter of 2017).

\section{Discussion: many actions, slim results}

Despite almost 20 years of practising innovation policies, many indictors reveal that Croatia has not progressed much in the economy, in technology, or in innovation during the last decade. On the contrary, the most recent analyses show that the Croatian economy is less competitive than its peers. There is a worrying trend which shows a general "lagging behind" of the countries of the former Soviet Union, which were behind Croatia in the era of socialism. In the last couple of years, Croatia can be seen to lag behind not only Hungary, Poland, the Czech Republic, and Slovenia, which used to be Croatia's peers, but also behind countries such as Bulgaria and Romania, which have always been behind the rest of Europe. It seems that these countries too will soon leave Croatia behind.

This simply means that Croatian development policies in general, and innovation policies in particular, for both research-based and non-research-based innovation, have simply been wasted efforts to spur the economic development and competences of entrepreneurs. The Croatian innovation system is widely perceived to be inefficient, 


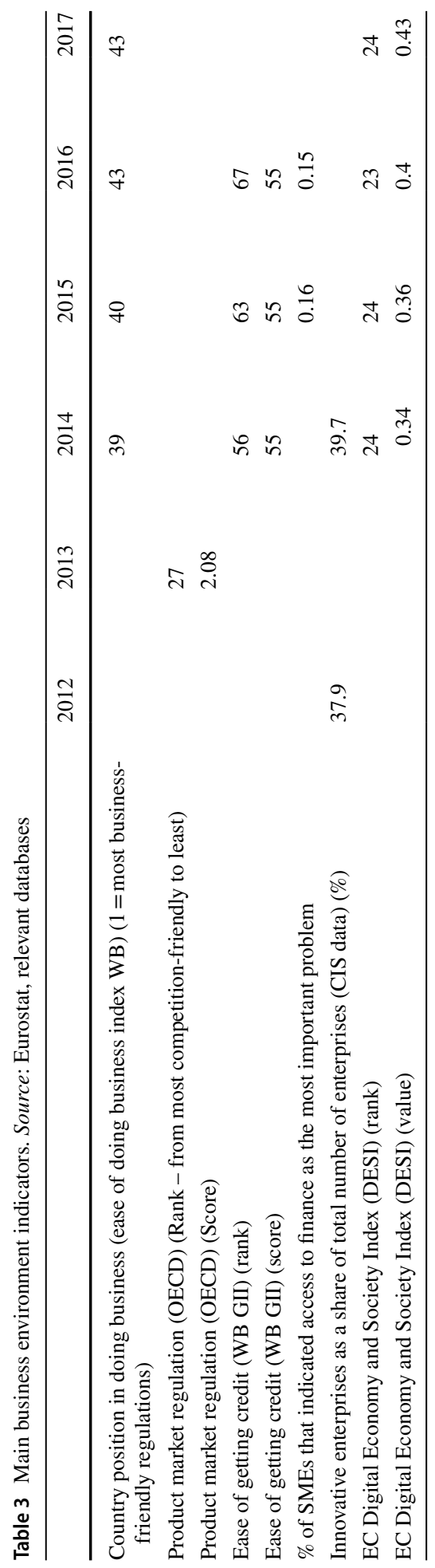


characterised by fragmentation, subscale investments, and poorly defined policies (European Commission 2015).

Investments by Croatian companies in R\&I remain rather low, reaching only $0.38 \%$ of GDP in 2016. This is the second lowest investment level among EU countries, second only to companies in Romania, who invested less in 2016. Public expenditure on R\&I amounted to $55.2 \%$ of GERD, while business expenditure on R\&D (BERD) amounted to $44.8 \%$ of GERD. Private companies also contributed $8.4 \%$ of their total funds to R\&I activities in universities, and $8 \%$ of their funds to the governmental R\&I sector. Science-industry cooperation with regards to technological and economic change is rather modest, characterised by a "downwards path" limited to standardised services, measurements, and quality control, instead of an "upwards path" focused on the development of new high-tech products and processes. Croatian companies invest only $€ 42$ per inhabitant, which is nine times less than the EU average. Business investment in R\&I is concentrated in only a small number of sectors, including-pharmacy (34\%), communications equipment (13\%), and motor vehicles (10\%).

It is worth mentioning that a rich landscape of over 350 business-supporting institutions (e.g. business incubations, entrepreneurial zones, etc.), complemented by a number of supporting programmes intended to increase the innovation capacities of SMEs, turned out to be of modest efficiency. According to the latest GEM report (Singer et al. 2018), Croatian companies mainly invested in technological infrastructure (e.g. machinery), while new product investments were scarce: $72 \%$ of newly established companies and $83 \%$ of "old" companies did not produce "new to the market products" in 2017. This means that Croatian companies belong to the "red ocean", in which competitors fight for dominance in the markets of known products, as opposed to the "blue ocean", where demand is created by new products.

Technology transfer polices and policies for fostering entrepreneurship have followed a different evolutionary path, both from an institutional and conceptual point of view. Entrepreneurship has developed, as described in Sect. 2 according to two plans (tycoon privatization and creation of traditional SME sector), which both followed their internal development logic and dynamics and largely ignored entrepreneurial innovation and new technologies. On the other hand, technology transfer has manly focused on the capitalization of science and research-based innovation, not taking into account the real needs of entrepreneurs. An attempt to merge these sectors into a single process took place rather recently through the Europeanization of research and technology transfer policy, determined by the concept of S3 and implemented through the bureaucratic rules and requirements of the ESIF Operational programmes.

The consequence is a concentration of $R \& D$ activities within the private business sector in only several large multinational companies, such as PLIVA (pharmaceuticals), Ericsson Nikola Tesla (ICT), Podravka (food industry), and Končar Electrical Engineering Institute (electrical engineering). Medium and large enterprises fund more than $90 \%$ of private investments in $\mathrm{R} \& \mathrm{D}$, with the highest portion of large enterprises investing in more than $60 \%$ of $R \& D$ investments. Less than $8 \%$ of private investments in R\&D come from micro and small enterprises, which is demonstrative of their lack of engagement in R\&D activities (OPCC 2014). Innovation potential in production sectors stems primarily from technological mastering and business sophistication in SMEs in medium-low and medium-high tech sectors, which consists of approximately $48 \%$ of a total of 11,560 SMEs in the manufacturing sector. Another $4.6 \%$ (more than 500 firms) are classified as high-tech (MEC 2013). 


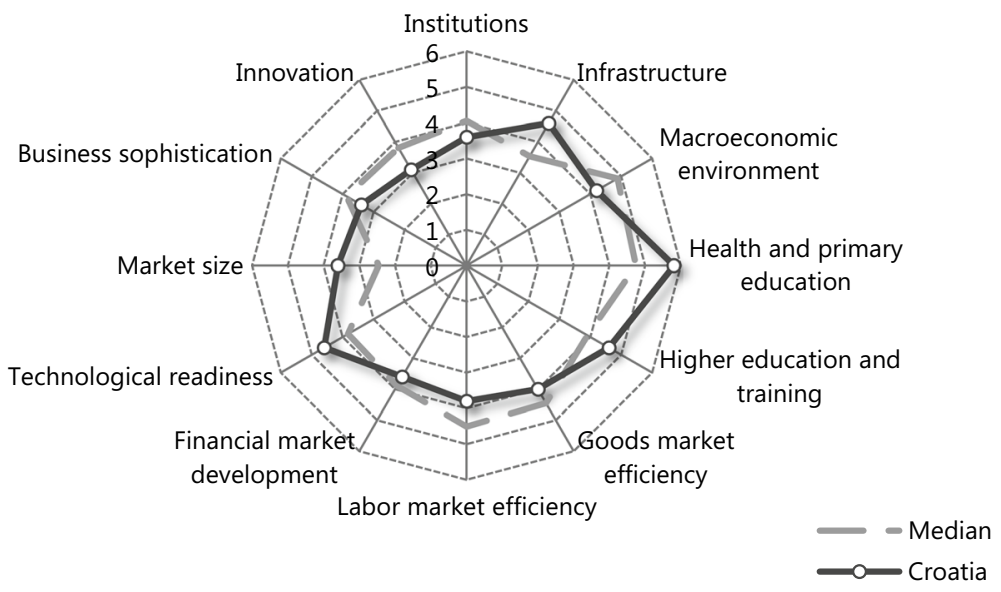

Fig. 2 Competitiveness performance overview of Croatia. Source: Global competitiveness report, 20152016

There are a number of nascent high-tech companies which have emerged in recent years, such as Genos and Genera in biomedicine, Pet minuta (5 min) in e-business, and Rimac in electrical car manufacture. It is worth mentioning the prominent rise SMEs in the IT sector (Bellabeat, MSAN group, Combis, IN2 group, etc.) which has, since 2013, become one of the 12 largest export branches of the Croatian economy. However, this small sector of companies does not compensate for the lost competences of the large amount of companies that collapsed throughout the 1990s.

The position of Croatia in terms of its international ranking for innovation, business, and competitiveness is rather low, despite its investments over the past few years, its efforts in creating more friendly business environments (e.g. lower minimum capital for start-up companies, reducing notary fees, etc.), and its environment for innovation. Its rank in the Ease of Doing Business indicator in the World Bank's Doing Business report (World Bank 2016) fell to the 51st position in 2017 from 43rd in 2016. The Global Innovation Index ranked Croatia in 41st place in 2017, which was an improvement on its ranking in 2016, in which it was 47th. However, Croatia's Market Sophistication and Business Sophistication indicators are still relatively weak (Croatia occupies 88th and 53rd position respectively). Its ranking for Ease of Starting a Business significantly declined (from 64th in 2016 to 76th in 2017) after the improvement recorded in 2016; and Ease of Getting Credit also showed a negative trend, as Croatia took 67th position in 2017, having fallen from 63rd position in 2016 (GII 2017). The Global Competitiveness Report, 2016-2017 (GCR 2016) indicated a similar performance: Croatia's overall ranking was 74th (out of 138 countries), with the lowest ranking being for its Innovation and Business Sophistication sub index (92nd). These factors overall influence the weak innovation performance of Croatia, which ranks 26th out of 28 EU Member States according to the European Innovation Scoreboard (EIS 2016). See Fig. 2.

Croatia is a moderate innovator amongst the EU Member States and performs below the EU average in all innovation dimensions except two (EIS 2016). These are human 
resources-Croatia is a leading country among the Member States in terms of its percentage of young people with upper secondary education-and non-R\&D innovation expenditure as a percentage of the total turnover of companies. However, in tertiary education attainment (see Sect. 3) and business R\&I expenditure, Croatia lags behind the EU average.

It is commonly believed that that the Croatian economy is locked into the low and medium technological growth model, and that one of the reasons for this (or perhaps as a consequence of this) is low investment in R\&I, particularly in the business sector. Croatia has experienced a downward trend in R\&D investments for more than a decade. According to Eurostat's latest data (March 2019), the total gross domestic expenditure on R\&D (GERD) amounted to $€ 402.3$ million ( $0.86 \%$ of GDP) in 2016, which represented an absolute annual increase on $€ 374.8$ million in 2015 (0.84\% of GDP). Public expenditure on R\&I amounted to $55.2 \%$ of GERD while business expenditure on R\&D amounted to $44.8 \%$ of GERD. Investments in R\&I in Croatia have experienced a downward trend for more than a decade (in 2004, GERD amounted to $1.3 \%$ of GDP) but, in recent years, the trend has been stagnant, which is insufficient to enable Croatia to catch up with more advanced economies. Overall, R\&I intensity in Croatia is significantly below both the $2.03 \%$ EU average and the national target of $1.4 \%$ set by the 2013 Economic Programme of Croatia. As such, the sustainability of R\&I funding for Croatia is expected to come mainly from ESIF from 2014 to 2020.

Liberalization of economy, market competition, privatization of companies, EU membership, and other benefits resulting from the collapse of socialism have not brought with them the expected socio-economic progress anticipated in the first enthusiastic decade of the transition to capitalism. The reasons behind this sluggish economic development, in which technological transfer was largely absent, are still the subject of bitter disputes. Economists mainly blame the wrong (neoliberal) growth model, based on financialization and excessive servitization of the economy (Radošević 2013), as well as classic obstructive elements, such as lack of managerial and strategic competences and entrepreneurial skills, strong national currency, or enormous bureaucracy and red tape.

Sociologists believe that inherited cultural factors, such as egalitarianism (Vuković et al. 2017), and socio-political trajectories known as the state of semi-modernism. Processes of de-industrialization, re-traditionalization, de-scientization, and irrational administration (Županov 2001) have resulted in the cognitive, social, and political inability of political elites to accept global transformations as necessary for global innovation-driven growth (Švarc 2006, 2017). Industrial and technological policies have largely been associated with the mere transition to market economy and the privatization of companies, while technological developments have not been taken into account.

Finally, political economists are more prone to finding obstacles in incorrect political systems, such as the "dependent market capitalism" (Nölke and Vliegenthart 2009) of the less developed countries in the European periphery. In Croatia, this specific type of crony capitalism was established during the first decade of transition. The characteristics of crony capitalism were described by Franičević and Bićanić (2007), and consist of systemic corruption and clientelism, which permeate all segments of economy and society, and divert companies' focus from innovation and export-oriented businesses towards political protection and support from interest groups to help sustain their business and their own prosperity ( ̌́varc 2017). 


\section{Implications}

The implications of the given analysis are rather straightforward. Croatia urgently needs to recover its economy and to accelerate its integration with the EU. The entrepreneurial innovation and UTT are essential components of this process but are not sufficient and self-sustained. They are currently well supported within the framework of S3 and ESIF funds and both sides (scientific community and entrepreneurs) should take advantage of this European support and assistance. Seeking to increase the proper use of funds, the policy-maker should understand how the system of cooperation operates and how it functions in practice to avoid bureaucratic implementation of the ESIF programmes and administrative allocation of the funds. The organic interest among stakeholders should be found and exchanged for formal implementation of the programmes involving only administrative "business as usual" procedures (calls, evaluation, funding). In this line, more effort is needed from the local, regional, and national authorities to coordinate the entrepreneurial discovery process and to spur entrepreneurial innovation. More coordination is required in order to identify and implement ambitious joint projects and the strategic entrepreneurial innovation of broader economic interests or grand challenges. The inclusion of Croatia in the global value chains is wholly neglected in the innovation policies; however, other countries, such as those of Visegrad (Slovakia, Poland Hungary, Czech Republic), based their success precisely on their inclusion in the global value chains (GVC) (Grodzicki 2014). Research into the policy mix for technology and innovation upgrades through the variety of forms for GVC could be a fruitful future policy orientation (Kergroach 2017).

The benchmark analyses of the Croatian economy provide clear evidence that supporting programmes, either for science/industry cooperation or for the business competitiveness of traditional SME, have not delivered the desired economic growth. Therefore, it is necessary to look beyond European programmes to diagnose the roots of slow growth. Many analyses, including this one, point out that economic recovery requires complex socio-economic transformations, which have been slowed down in Croatia by the lack of action taken towards "economic hygiene", or "getting the fundamentals right" (OECD 2001). The research implies that fundamentals, such as well-functioning markets, institutions, governance, and favourable macroeconomic conditions, as described in the World Bank report (2013) and European semester (European Commission 2015), should be established to raise Croatian competitiveness from last place in the EU.

The next policy actions involve fostering entrepreneurs, technology development, innovation, and scientific research, which is needed to re-affirm Croatia on international competitiveness and business scales. Because of the low technological capacities of firms, it would be useful to consider the unorthodox idea of the division of labour between public research and private businesses (Dosi et al. 2006) to allow both spheres to develop through their inherent logic and dynamics. The mastery of productive entrepreneurship, and its ability to create demand for R\&D (Radošević 2006) and the entrepreneurship abilities of the population in general, should be strengthened on the "entrepreneurial pole" of the process. The prerequisite is the completion of the privatization process of the state companies, as well as intensive efforts against crony capitalism as a phenomenon adverse to entrepreneurial innovation and technology development.

On the "science pole," it is necessary to assure the sustainability of the scientific research system and the national knowledge base, which is a distinct process not crucially related to entrepreneurship. The concepts of entrepreneurial economy and the national entrepreneurial system point out that entrepreneurship and science can develop separately. 
Entrepreneurial innovation does not necessarily involve R\&D, while academics should be required to develop their "islands" of excellence," cutting-edge research, and technological frontiers to fulfil their social and economic role, which is a prerequisite for developing research-based entrepreneurial innovation.

\section{Conclusions}

This research analyses the evolution path of the UTT in post-socialist countries, using Croatia as an example of this, with the aim of establishing whether or not the transition to capitalism and membership in the EU has enhanced UTT practices and related entrepreneurial innovation, and whether academic knowledge and research has filtered down to cultivate valuable economic activities and marketable innovation under these new circumstances.

The main contribution of the research is the identification of three models of UTT in transition countries using the longitudinal case study of Croatia: the science based model, which was practiced in socialism; endeavours towards an innovation based model during the transition period; and a bureaucratic UTT model, driven by the EU cohesion policy and access to the European Structural Funds. Insights into the evolution of these models suggests the following three relevant conclusions.

Firstly, the sluggish economic growth and technological stagnancy of the country suggest that there is no substantial difference in the efficiency of the different UTT models, which were in operation in different socio-political regimes. The proficiency of UTT was not improved during the switch from socialism to capitalism, nor through Croatia's membership in the EU, and is thus shown to have little influence on entrepreneurial innovation. UTT continues to suffer from almost the same shortcomings nowadays as it did in the era of socialism and in its transitional period. Fragmentation of the innovation system, poor connections between science and business sectors, low technology and innovation capacities of companies, low business investments in $\mathrm{R} \& \mathrm{D}$, technological obsolescence of equipment, narrow technological trajectories, and the low interest of companies in innovation and cooperation within research sectors have all largely remained the same.

Secondly, the suppression of innovativeness, entrepreneurship, and competition, which would otherwise stimulate UTT, is still strongly present, although it is based on different premises-primarily on the wrong growth model and crony capitalism. Sources of growth throughout a significant part of the transition were based on domestic consumption, defensive inter-sectoral restructuring (dismissal of workers or early retirement), and lowtechnology foreign direct investments (FDI) (Lovrinčević and Teodorović 1998), instead of market competition, innovation, and technological upgrading. This model was not sustainable in the long run, and it led to poor market dynamism and a business environment that needed stimulation in the later stages of the development of its national competitiveness. This has contributed to the structural deficiencies of the R\&D business sector in terms of low business investment in $R \& D$ and insufficient human resources for innovation dynamics within firms. Governance of innovations is often reduced to the buying of new machinery, incremental modifications, and products/processes which exclude risk taking and lead to low economic effect and non-export orientation. Negative effects also stem from the lack of transparency of corporate practices, and a close connection to state and authoritarian corporate management, which characterizes all periods of economic development, from socialism to the present day. 
Thirdly, the difficulties experienced throughout socialism, in terms of the practical application of research results and technological development, have not improved. The national innovation policy was launched in 2001 during the country's transition into capitalism and, as a result of a lack of entrepreneurial innovation, the inability of businesses to bridge the gap between scientific research and its commercial application, narrow-minded policy-makers, and incorrect growth models, it has never come to function as it was hoped it would. This confirms the results of previous research (Staehr 2011), which state that, while EU membership has advanced democratic reforms, the effect on market-economic reforms has been either non-existent or negative.

The overall results suggest that, despite the dramatic change from socialism to capitalism, the basic mechanisms of economic functioning, such as state paternalism, lack of competition, private initiatives, and weak entrepreneurship, remain constant and produce modest improvements in the practices of UTT. Subsequently, sound action of the national government is needed to overcome economic and technological stagnation, and to exploit the benefits of the EU integration policies and ESIF.

The main limitation of this research refers to the qualitative methodology approach due to a lack of objective and systematized data for discussing the performance of technology transfer and entrepreneurship policy. Although the longitudinal case study and qualitative interpretive approach is an excellent method for critical analyses and understudying how the national socio-economic and political context determines technology transfer and entrepreneurial innovation, a lack of statistical data and empirical information about $R \& D$, innovation, and entrepreneurship limit the achievements and scope of this research. It mainly concerns a lack of systemized data about ESIF operational programmes (projects, stakeholders, beneficiaries, the share in national funds for R\&D, etc.) The available international benchmarks and reports are not sufficient for efficient governance and the strategic coordination of innovation and entrepreneurship. A system of data collection, evaluation methods, and indicators should be established for diagnostic analyses (Edquist 2011), evidence-based innovation policy (Gault 2018), and better leverage of European funds. Therefore, future research should be focused on comprehensive empirical research and data collection concerning UTT, entrepreneurial innovation, and performance of the ESIF operational programmes, with a view to explore their influence on national entrepreneurship, innovation, and scientific potential, along with their inclusion into the global value chains.

Open Access This article is distributed under the terms of the Creative Commons Attribution 4.0 International License (http://creativecommons.org/licenses/by/4.0/), which permits unrestricted use, distribution, and reproduction in any medium, provided you give appropriate credit to the original author(s) and the source, provide a link to the Creative Commons license, and indicate if changes were made.

\section{References}

Acs, J. Z., \& Audretsch, B. D. (2005). Entrepreneurship, innovation and technological change. Foundations and Trends in Entrepreneurship, 1(4), 149-195. https://doi.org/10.1561/0300000004.

Acs, J. Z., Audretsch, D. B., \& Lehmann, E. E. (2017). National system of innovation. The Journal of Technology Transfer, 42(5), 997-1008.

Acs, Z., Autio, E., \& Szerb, L. (2014). National systems of entrepreneurship: Measurement issues and policy implications. Research Policy, 43(3), 476-494.

Allen, T. J., \& O'Shea, R. (Eds.). (2014). Building technology transfer within research universities: An entrepreneurial approach. Cambridge: Cambridge University Press. 
Anić, I. D., Bačić, K., \& Aralica, Z. (2018). The competitiveness clusters in Croatia. Ekonomski Pregled, 69(5), 571-593.

Archibugi, D., \& Filippetti, A. (2011). Is the economic crisis impairing convergence in innovation performance across Europe? Journal of Common Market Studies, 49, 1153-1182. https://doi.org/10.111 1/j.1468-5965.2011.02191.x.

Audretsch, D. B. (2007). Entrepreneurship capital and economic growth. Oxford Review of Economic Policy, 23(1), 63-78.

Audretsch, D. B. (2018). Entrepreneurship, economic growth, and geography. Oxford Review of Economic Policy, 34(4), 637-651.

Audretsch, D., \& Caiazza, R. (2016). Technology transfer and entrepreneurship: Cross-national analysis. Journal of Technology Transfer, 41, 1247-1259. https://doi.org/10.1007/s10961-015-9441-8.

Audretsch, D. B., Lehmann, E. E., \& Wright, M. (2012). Technology transfer in a global economy. The Journal of Technology Transfer, 39(3), 301-312. https://doi.org/10.1007/s10961-012-9283-6.

Audretsch, D. B., \& Link, A. N. (2018). Innovation capital. The Journal of Technology Transfer, 43, 17601767. https://doi.org/10.1007/s10961-018-9700-6.

Autio, E., Kenney, M., Mustar, P., Siegel, D., \& Wright, M. (2014). Entrepreneurial innovation: The importance of context. Research Policy, 43(7), 1097-1108.

Balconi, M., Brusoni, S., \& Orsenigo, L. (2010). In defence of the linear model: An essay. Research Policy, 39(1), 1-13.

Bartllet, W. (2003). Croatia between Europe and the Balkans. London: Routledge.

Block, J. H., Thurik, R., \& Zhou, H. (2013). What turns knowledge into innovative products? The role of entrepreneurship and knowledge spillovers. Journal of Evolutionary Economics, 23(4), 693-718. https://doi.org/10.1007/s00191-012-0265-5.

Bonaccorsi, A. (2016). Addressing the disenchantment: Universities and regional development in peripheral regions. Journal of Economic Policy Reform, 20, 293. https://doi.org/10.1080/17487870.2016.12127 11 .

Bozeman, B., Rimes, H., \& Youtiem, J. (2015). The evolving state-of-the-art in technology transfer research: Revisiting the contingent effectiveness model. Research Policy, 44, 34-49.

Breznitz, S. M., \& Etzkowitz, H. (Eds.). (2016). University technology transfer: The globalization of academic innovation. New York: Routledge.

Breznitz, S. M., \& Feldman, M. P. (2010). The engaged university. The Journal of Technology Transfer, 37(2), 139-157. https://doi.org/10.1007/s10961-010-9183-6.

Burhan, N. A. S., Razak, R. C., Salleh, F., Labastida, M. E., \& Tovar, M. E. L. (2017). The higher intelligence of the 'creative minority' provides the infrastructure for entrepreneurial innovation. Intelligence, 65, 93-106.

Carlsson, B., Braunerhjelm, P., McKelvey, M., Olofsson, C., Persson, L., \& Ylinenpaa, H. (2013). The evolving domain of entrepreneurship research. Small Business Economics, 42, 913-930. https://doi. org/10.1007/s11187-013-9503-y.

CEU. (2016). Council recommendations on the 2017 National Reform Programme of Croatia and delivering a Council opinion on the 2017 Convergence Programme of Croatia, Council of the European Union, Brussels. COM(2017) 510 final. https://ec.europa.eu/info/sites/info/files/2017-european-semes ter-country-specific-recommendations-commission-recommendations-croatia.pdf. Accessed $12 \mathrm{Apr}$ 2019.

Dabic, M., Daim, T., Bayraktaroglu, E., Novak, I., \& Basic, M. (2012). Exploring gender differences in attitudes of university students towards entrepreneurship. International Journal of Gender and Entrepreneurship, 4(3), 316-336.

Dabić, M., Gonzalez-Loureiro, M., \& Daim, T. U. (2015a). Unraveling the attitudes on entrepreneurial universities: The case of Croatian and Spanish universities. Technology and Society, 42, 167-178.

Dabić, M., Švarc, J., \& Bečić, E. (2015b). A multidimensional approach to the environment for entrepreneurship in selected CE countries. International Journal of Transitions and Innovation Systems, 3-4(3), 295-328.

Dabić, M., Śvarc, J., \& González-Loureiro, M. (2016). Entrepreneurial universities in innovation-seeking countries: Challenges and opportunities. NewYork: Palgrave Macmillan.

Dosi, G., Llerena, P., \& Labini, M. S. (2006). The relationship between science, technologies and their industrial exploitation: An illustration through the myths and realities of the so-called "European paradox". Research Policy, 35, 1450-1464.

Drucker, P. F. (1985). Innovation and entrepreneurship. New York: Harper and Row.

Dyker, D. A. (2011). Yugoslavia: Socialism, development, and debt. New York: Routledge.

Dyker, D. A., \& Radošević, S. (Eds.). (1999). Innovation and structural change in post-socialist countries: A quantitative approach. Dordrecht: Kluwer Academic Publishers. 
Dyker, D. A., \& Vejvoda, I. (Eds.). (2014). Yugoslavia and after: A study in fragmentation, despair and rebirth. London: Routledge.

Edquist, C. (2011). Design of innovation policy through diagnostic analysis: Identification of systemic problems (or failures). Industrial and Corporate Change, 20, 1725. https://doi.org/10.1093/icc/dtr060.

Edquist, C., \& Lundvall, B. A. (1993). Comparing the Danish and Swedish systems of innovation. In R. R. Nelson (Ed.), National innovation systems: A comparative analysis (pp. 265-298). New York: Oxford University Press.

EIS. (2016). European innovation scoreboard 2016. European Commission, Brussels . http://ec.europa.eu/ growth/industry/innovation/facts-figures/scoreboards_en. Accessed 30 May 2017.

Estrin, S., \& Mickiewicz, T. (2011). Entrepreneurship in transition economies: The role of institutions and generational change. In M. Minniti (Ed.), The dynamics of entrepreneurship: Evidence from global entrepreneurship (pp. 181-209). Oxford: Oxford University Press.

Etzkowitz, H. (2008). The triple helix: University-industry-government innovation in action. London: Taylor and Francis Group.

Etzkowitz, H., \& Viale, R. (2010). Polyvalent knowledge and the entrepreneurial university: A third academic revolution? Critical Sociology, 36(4), 595-609.

European Commission. (1995). Green paper on innovation. Luxembourg: Directorate XIII/D.

European Commission. (2000). Towards a European research area, Brussels, 18 January 2000, [COM (2000), (Lisbon agenda)].

European Commission. (2015). Country report Croatia 2015: Including an in-depth review on the prevention and correction of macroeconomic imbalances (European Semester), SWD(2015) 30 final, Brussels. http://ec.europa.eu/europe2020/pdf/csr2015/cr2015_croatia_en.pdf. Accessed 29 May 2017.

Foray, D., David, P. A., \& Hall, B. (2009). Smart specialisation-the concept, knowledge economists. Policy Brief No. 9. http://ec.europa.eu/invest-in-research/pdf/download_en/kfg_policy_brief_no9. pdf. Accessed 15th Sept 2018.

Franičević, V., \& Bićanić, I. (2007). EU accession and Croatia’s two economic goals: Modern economic growth and modern regulated capitalism. Southeast European and Black Sea Studies, 7, 637-663.

Freeman, C. (1988). Japan: A new national system of innovation? In G. Dosi, et al. (Eds.), Technical change and economic theory (pp. 330-349). London: Pinter Publisher Limited.

Garud, R., Gehman, J., \& Giuliani, A. P. (2014). Contextualizing entrepreneurial innovation: A narrative perspective. Research Policy, 43(7), 1177-1188.

Gault, F. (2018). Defining and measuring innovation in all sectors of the economy. Research Policy, 47, 617-622.

GCR. (2016). Global competitiveness report 2016-2017. Geneva: World Economic Forum. https://www. weforum.org/reports/the-global-competitiveness-report-2016-2017-1. Accessed 29 June 2017.

Gibb, A., \& Hannon, P. (2006). Towards the entrepreneurial university. International Journal of Entrepreneurship Education, 4(1), 73-110.

Global Innovation Index. (2017). Innovation feeding the world (10th ed.). In S. Dutta, B. Lanvin \& V. S. Wunschs (Eds.). https://www.wipo.int/edocs/pubdocs/en/wipo_pub_gii_2017.pdf. Accessed 15 Sept 2018.

González-Cruz, T., \& Devece, C. (2018). Entrepreneurial innovation, judgment, and decision-making as a virtuous process. International Entrepreneurship and Management Journal, 14(2), 245-248.

Grodzicki, M. J. (2014). Global value chain and competitiveness of V4 economies (chapter 1). In D. Kiendl-Wendner \& K. Wach (Eds.), International competitiveness in Visegrad countries: Macro and micro perspectives (pp. 13-31). Graz: Fachhochschule Joanneum.

Guerrero, M., \& Urbano, D. (2017). The impact of Triple Helix agents on entrepreneurial innovations' performance: An inside look at enterprises located in an emerging economy. Technological Forecasting and Social Change, 119, 294-309.

Guerrero, M., Urbano, D., \& Fayolle, A. (2016). Entrepreneurial activity and regional competitiveness: Evidence from European entrepreneurial universities. Journal of Technology Transfer, 41(1), $105-131$.

Hanson, P., \& Pavitt, K. (1987). The comparative economics of research development and innovation in east and west: A survey. Chur: Harwood Academic Publishers.

Högselius, P. (2003). Can east European countries innovate? Paper prepared for the DRUID winter conference, Aalborg, 16-18 January.

IDIS. (1980). Science in Yugoslavia. Zagreb: Institute of Social Research (IDIS). (in Croatian).

Ignatov, A. (2017). Entrepreneurial innovation: The European Union perspective. Review of Economic Perspectives, 18(2), 137-154. https://doi.org/10.2478/revecp-2018-0008. 
Jeleč Raguž, M., \& Mujić Mehičić, N. (2017). The influence of science-industry collaboration on firms' innovative performance-Evidence from the Republic of Croatia. Economic Research 30(1), 9921002. https://doi.org/10.1080/1331677X.2017.1314819. Accessed 15th Aug 2018.

Kergroach, S. (2018). National innovation policies for technology upgrading through GVCs: A crosscountry comparison. Technological Forecasting and Social Change. https://doi.org/10.1016/j.techf ore.2018.04.033.

Kornai, J. (2010). Innovation and dynamism: Interaction between systems and technical progress. The Economics of Transition, 18, 629-670. https://doi.org/10.1111/j.1468-0351.2010.00396.x.

Krammer, S. M. S. (2009). Drivers of national innovation in transition: Evidence from a panel of Eastern European countries. Research Policy, 38(5), 845-860. https://doi.org/10.1016/j.respo 1.2009 .01 .022 .

Kshetri, N. (2009). Entrepreneurship in post-socialist economies: A typology and institutional contexts for market entrepreneurship. Journal of International Entrepreneurship, 7(3), 236-259.

Kuhlmann, S. (2001). Future governance of innovation policy in Europe-Three scenarios. Research Policy, 30(6), 953-976.

Landström, H., \& Harirchi, G. (2018). The social structure of entrepreneurship as a scientific field. Research Policy, 47, 650-662.

Lange, S., \& Švarc, J. (Eds.). (1994). Workshop proceedings. Julich: Forschungszentrum Julich GmbH.

Liargovas, P., Petropoulos, S., Tzifakis, N., \& Huliaras, A. (Eds.). (2016). Beyond “absorption”: The impact of EU structural funds on Greece. Athens: Konrad-Adenauer Stiftung.

López Mendoza, X. P., \& Mauricio Sanchez, D. S. (2018). A systematic literature review on technology transfer from university to industry. International Journal of Business and Systems Research, 12(2), 197. https://doi.org/10.1504/ijbsr.2018.10010090.

Lovrinčević, Ž., \& Teodorović, I. (1998). Condition and tendencies of the Croatian economy in the period 1994 to 1998. Ekonomski pregled, 49(7-8), 699-717. (in Croatian).

MEC. (2013). Report of the small and medium entrepreneurship observatory in the Republic of Croatia. Ministry of Entrepreneurship and Crafts, Zagreb. http://www.efos.unios.hr/suvremene-poslovneaktivnosti/wp-content/uploads/sites/137/2013/04/HR-Final.pdf. Accessed 29 May 2017.

Meske, W. (Ed.). (2000a). From system transformation to European integration: Science and technology in Central and Eastern Europe at the beginning of the 21st century. Piscataway: Transaction Publishers.

Meske, W. (2000b). Science and technology in CEECs in the socialist era. In W. Meske (Ed.), From system transformation to European integration: Science and technology in Central and Eastern Europe at the beginning of the 21st century (pp. 7-27). Piscataway: Transaction Publishers.

Miller, K., Alexander, A., Cunningham, J. A., \& Albats, E. (2018). Entrepreneurial academics and academic entrepreneurs: A systematic literature review. International Journal of Technology Management, 77(1-3), 9-38.

MoST. (2002). Croatian program for innovative technological development (HITRA): Collected programmatic papers. Zagreb: Ministry of Science and Technology.

Mrozewski, M., \& Kratzer, J. (2017). Entrepreneurship and country-level innovation: Investigating the role of entrepreneurial opportunities. Journal of Technology Transfer, 42(5), 1125-1142. https://doi. org/10.1007/s10961-016-9479-2.

Mršić, A. (2018). The processes of defining the problems and priorities in innovation policy making in Croatia from the perspective of discursive institutionalism. University of Zagreb, Faculty of Political Sciences, Doctoral Dissertation (in Croatian).

Muscio, A., Reid, A., \& Rivera Leon, L. (2015). An empirical test of the regional innovation paradox: Can smart specialisation overcome the paradox in Central and Eastern Europe? Journal of Economic Policy Reform, 18(2), 153-171. https://doi.org/10.1080/17487870.2015.1013545.

Mytelka, L. K., \& Smith, K. (2002). Policy learning and innovation theory: An interactive and co-evolving process. Research Policy, 31, 1467-1479.

Nelson, R. (Ed.). (1993). National Innovation Systems. A comparative analysis. New York: Oxford University Press.

Nelson, R. R., \& Winter, S. G. (1982). An evolutionary theory of economic change. Cambridge: The Belknap Press of Harvard University Press.

Nölke, A., \& Vliegenthart, A. (2009). Enlarging the varieties of capitalism: The emergence of dependent market economies in East Central Europe. World Politics, 61, 670-702. https://doi.org/10.1080/14683 850701726104.

OECD. (1992). Technology and economy: The key relationships. Paris: OECD.

OECD. (1998). Science, technology and industry outlook. Paris: OECD.

OECD. (2001). The new economy: Beyond the hype. Paris: OECD. 
OPCC. (2014). Operation programme competiveness and cohesion. https://www.mingo.hr/public/investicij e/OPKK_2014_2020_31316.pdf. Accessed 12 Apr 2019.

Perkmann, M., Tartari, V., McKelvey, M., Autio, E., Brostrom, A., D’Este, P., et al. (2013). Academic engagement and commercialisation: A review of the literature on university-industry relations. Research Policy, 42(2), 423-442.

Pisk, K. (2001). Cooperation of science and industry, presentation at the fifth multidisciplinary conference: Technical Sciences for the Croatian economy. Zagreb: Croatian Academy of Engineering and Croatian Systems Society. (in Croatian).

Prpić, K. (2003). Social marginalization of science and development of the Croatian research potentials. Social Issues, 12(1-2), 45-68. (in Croatian).

Radas, S. (2006). Collaboration between industry and science: Motivation factors, collaboration intensity and collaboration outcome. Croatian Economic Survey, 8(1), 11-31.

Radosević, S. (1994). Strategic technology policy for Eastern Europe. Economic Systems, 18(2), 87-116.

Radosević, S. (1996). Restructuring of R\&D institutes in post-socialistic economies: Emerging patterns and issues. In A. Webster (Ed.), Building new bases for innovation: The transformation of the $R \& D$ system in post-socialist states (pp. 8-31). Cambridge: Anglia Polytechnic University.

Radošević, S. (2006). Research and development, competitiveness and European integration of South Eastern Europe. Europe-Asia Studies, 61(4), 621-650.

Radošević, D. (2013). Development strategy for Croatia 2014-2020. Ekonomski pregled, 64(3), 187-212. (in Croatian).

Radošević, S. (2018). Assessing EU smart specialization policy in a comparative perspective. In S. Radosevic, et al. (Eds.), Advances in the theory and practice of smart specialization (pp. 2-31). Amsterdam: Elsevier Academic Press.

Radošević, S., Curaj, A., Gheorghiu, R., Andreescu, L., \& Wade, I. (Eds.). (2018). Advances in the theory and practice of smart specialization. Amsterdam: Elsevier Academic Press.

Rhoades, G., \& Slaughter, S. (1997). Academic capitalism, managed professionals, and supply-side higher education. Social Text, 51, 9-38.

Schumpeter, J. A. (1942). Capitalism, socialism and democracy. New York: Harper \& Brothers.

Shane, S. (2009). Why encouraging more people to become entrepreneurs is bad public policy. Small Business Economy, 33(2), 141-149.

Silva, C. E., Esteves, F., Narcizo, R. B., \& Cardoso, R. (2018). Concepts and criteria for the characterization of the entrepreneurial university: A systematic literature review. Journal of Economics, Business and Management, 6(3), 65-71.

Singer, S., Šarlija, N., Pfeifer, S., \& Oberman Peterka, S. (2018). Global entrepreneurship monitor Croatia 2016: What makes Croatia a (non-)entrepreneurial country?. Zagreb: CEPOR. (in Croatian).

Slaughter, S., \& Leslie, L. L. (2001). Expanding and elaborating the concept of academic capitalism. Organization, 8(2), 154-161.

Staehr, K. (2011). Democratic and market-economic reforms in the post-communist countries. Eastern European Economics, 49(5), 5-28. https://doi.org/10.2753/eee0012-8775490501.

Stipetić, V. (2012). Two centuries of the Croatian economy (1820-2005). Zagreb: HAZU. (in Croatian).

Švarc, J. (2006). Socio-political factors and the failure of innovation policy in Croatia as a country in transition. Research Policy, 35(1), 144-159.

Švarc, J. (2011). Does Croatian national innovation system (NIS) follow the path towards knowledge economy? International Journal of Technology Transfer and Commercialisation, 10(2), 131-151.

Švarc, J. (2014). A triple helix systems approach to strengthening the innovation potential of the Western Balkan countries. International Journal of Transitions and Innovation Systems, 3(3), 169-188. https://doi.org/10.1504/IJTIS.2014.065698.

Švarc, J. (2017). Socio-political approach in exploring the innovation culture in post-socialist countries: The case of Croatia. Post-Communist Economies, 29(3), 359-374. https://doi.org/10.1080/14631 377.2017.1315001.

Szerb, L. A., Acs, Z., \& Autio, E. (2013a). Entrepreneurship and policy: The national system of entrepreneurship in the European Union and in its member countries. Entrepreneurship Research Journal, 3(1), 9-34.

Szerb, L., Aidis, R., \& Acs, J. Z. (2013b). The comparison of the global entrepreneurship monitor and the global entrepreneurship and development index methodologies. Foundations and Trend in Entrepreneurship, 9, 1-142. https://doi.org/10.1561/0300000046.

Thurik, A. R., Stam, E., \& Audretsch, D. B. (2013). The rise of the entrepreneurial economy and the future of dynamic capitalism. Technovation, 33(8-9), 302-310. https://doi.org/10.1016/j.techn ovation.2013.07.003. 
Uvalić, M. (2018). The rise and fall of market socialism in Yugoslavia DOC Research Institute, special report. https://doc-research.org/2018/03/rise-fall-market-socialism-yugoslavia. Accessed 3rd Sept 2018.

Vehovec, M., \& Radas, S. (2006). Industry science collaboration in Croatia: Academics' view. Društvena Istraživanja, 3(83), 345-369.

Vuković, V., Štulhofer, A., \& Burić, I. (2017). Was Županov right? Testing the origin and persistence of the egalitarian syndrome. Društvena Istraživanja, 26(2), 207-225. https://doi.org/10.5559/ di.26.2.04. (in Croatian).

Wahab, S. A., Rose, R., \& Osman, S. I. W. (2012). Defining the concepts of technology and technology transfer: A literature analysis. International Business Research, 5(1), 61-71. https://doi. org/10.5539/ibr.v5n1p61.

World Bank. (2013). Country papers series: Croatia, technical assistance project (P123211), World Bank. http://www.worldbank.org/content/dam/Worldbank/document/eca/Western-Balkans-R\&DCroatia.pdf. Accessed 12 Apr 2019.

World Bank. (2012). Croatia partnership country program snapshot, World Bank Group, April 2012. http://www.worldbank.org/content/dam/Worldbank/document/CroatiaSnapshotApril2012.pdf. Accessed 12 Apr 2019.

World Bank. (2016). The world bank annual report. Washington, DC: CWorld Bank. https://openknowle dge.worldbank.org/handle/10986/24985.

Županov, J. (2001). The industrializing and de-industrializing elite in Croatia in the second half of the 20th century. In D. Čengić \& I. Rogić (Eds.), Ruling elites within an analytic perspective (pp. 11-37). Zagreb: Institute of Social Sciences Ivo Pilar. (in Croatian).

Publisher's Note Springer Nature remains neutral with regard to jurisdictional claims in published maps and institutional affiliations. 